\title{
Aluminium w budowie zbiorników ciśnieniowych - Wymagania dotyczące materiałów rodzajów złączy technologii spawania kontroli i badań wg PN-EN 13445-8:2009
}

\author{
Aluminium in the construction of pressure vessels \\ - Requirements for materials welding technology types \\ of joints controls and testing \\ according to PN-EN 13445-8: 2009
}

\section{Streszczenie}

W artykule przedstawiono wymagania dotyczące wytwarzania zbiorników ciśnieniowych z aluminium i jego stopów określone w PN-EN 13445-8:2009 [1]. Opisano szczegółowo zagadnienia obejmujące: wybór materiałów podstawowych, ograniczenia stosowania niektórych rodzajów złączy spawanych, technologię spawania oraz badania złączy spawanych.

Słowa kluczowe: zbiorniki ciśnieniowe; aluminium, technologia spawania

\section{Abstract}

The paper presents manufacturing issues for pressure vessels of aluminium and aluminium alloys specified in the standard of PN-EN 13445-8:2009 [1]. A choice of parent materials, limitations for some types of welded joints, welding procedures and examinations of welded joints have been described in details.

Keywords: pressure vessels; aluminium; welding procedure

\section{Wstęp}

Zbiorniki ciśnieniowe wytwarzane $z$ aluminium i jego stopów stanowią grupę urządzeń ciśnieniowych dla których opracowywane są oddzielne, specjalne wymagania.

Celem artykułu jest przedstawienie wybranych zagadnień związanych z zastosowaniem aluminium i jego stopów do budowy zbiorników ciśnieniowych na podstawie PN-EN 13445-8:2009 [1], która jest zharmonizowana z dyrektywą ciśnieniową 97/23/WE.

Zakres niniejszej publikacji obejmuje wymagania dotyczące materiałów, rodzajów złączy, technologii spawania oraz badań połączeń spawanych.

W przypadku niektórych wymagań wprowadzono uzupełniające informacje zawarte $w$ innych normach szczegółowych $[2 \div 4,6,7]$.

\section{Wymagania dotyczące materiałów}

Spośród szerokiego asortymentu aluminium i jego stopów, do wytwarzania urządzeń ciśnieniowych stosuje się tylko niektóre ich rodzaje, w szczególności przerobione plastycznie przy czym stopy obrabiane cieplnie (utwardzane wydzieleniowo) wykorzystać można w bardzo ograniczonym zakresie. Podstawę wyboru stanowią przede wszystkim następujące czynniki:

- własności mechaniczne (granica plastyczności, wytrzymałość na rozciąganie, wydłużenie, wytrzymałość zmęczeniowa),

- spawalność,

- odporność na korozję (w tym również na korozję naprężeniową i międzykrystaliczną).

Do wytwarzania urządzeń ciśnieniowych można stosować aluminium i jego stopy określone w tablicy I [1].

Skład chemiczny powinien odpowiadać specyfikacji materiałowej (PN-EN 573-3:2014-02 [5]) przy czym zawartość ołowiu nie może być większa niż $150 \mu \mathrm{g} / \mathrm{g}$. Zaleca się aby materiał przeznaczony na elementy podlegające spawaniu wytworzony był z wlewków poddanych walcowaniu lub wyciskaniu o zawartości wodoru nie większej niż 0,2 ml/100 g mierzonej w ciekłym metalu podczas odlewania.

Aluminium i stopy aluminium stosowane do wytwarzania elementów spawanych, które w procesie produkcyjnym podlegają zabiegom przeróbki plastycznej na zimno powinny cechować się wydłużeniem nie mniejszym niż 14\% (niezależnie od kierunku pobierania próbek) przy zachowaniu długości pomiarowej $L o=5,65 \sqrt{\text { So }}$

Mgr inż. Arkadiusz Makówka, mgr inż. Adam Ogrodnik - Urząd Dozoru Technicznego.

Autor korespondencyjny/Corresponding author. arkadiusz.makowka@udt.gov.pl 
Tablica I. Aluminium i jego stopy przeznaczone do wytwarzania zbiorników ciśnieniowych Table I. Aluminium and aluminium alloys for manufacturing of pressure vessels

\begin{tabular}{|c|c|c|c|c|c|}
\hline \multirow{2}{*}{$\begin{array}{c}\text { Grupa } \\
\text { wg ISO/TR } \\
15608\end{array}$} & \multirow{2}{*}{$\begin{array}{l}\text { Podgrupa } \\
\text { wg ISO/TR } \\
15608\end{array}$} & \multirow[b]{2}{*}{ Opis materiału } & \multicolumn{3}{|c|}{ Oznaczenie } \\
\hline & & & Numer EN AW & $\begin{array}{c}\text { Symbol określający skład } \\
\text { chemiczny }\end{array}$ & Stan \\
\hline 21 & & $\begin{array}{l}\text { Czyste aluminium } \\
\text { o łącznej zawartości } \\
\text { składników stopowych } \\
\text { lub domieszek } \leq 1 \%\end{array}$ & $\begin{array}{l}\text { EN AW - 1050A } \\
\text { EN AW - 1070A } \\
\text { EN AW - 1080A }\end{array}$ & $\begin{array}{l}\text { EN AW - Al 99,5 } \\
\text { EN AW - Al 99,7 } \\
\text { EN AW - Al 99,8(A) }\end{array}$ & $\begin{array}{l}\mathrm{O}, \mathrm{H} 111, \mathrm{H} 112 \\
\mathrm{O}, \mathrm{H} 111, \mathrm{H} 112 \\
\mathrm{O}, \mathrm{H} 111, \mathrm{H} 112\end{array}$ \\
\hline \multirow{5}{*}{22} & \multicolumn{5}{|c|}{ Stopy nie obrabiane cieplnie } \\
\hline & 22.1 & $\begin{array}{l}\text { Stopy } \\
\text { aluminium-mangan }\end{array}$ & $\begin{array}{l}\text { EN AW - } 3003 \\
\text { EN AW } 3103 \\
\text { EN AW } 3105\end{array}$ & $\begin{array}{l}\text { EN AW-Al Mn1 Cu } \\
\text { EN AW-Al Mn1 } \\
\text { EN AW-Al Mn0,5Mg0,5 }\end{array}$ & $\begin{array}{l}\mathrm{O}, \mathrm{H} 111, \mathrm{H} 112 \\
\mathrm{O}, \mathrm{H} 111, \mathrm{H} 112 \\
\mathrm{O}, \mathrm{H} 111\end{array}$ \\
\hline & 22.2 & $\begin{array}{l}\text { Stopy } \\
\text { aluminium-magnez } \\
\text { o zawartości Mg } \leq 1,5 \%\end{array}$ & $\begin{array}{l}\text { EN AW - } 5005 \\
\text { EN AW - 5005A } \\
\text { EN AW - } 5050\end{array}$ & $\begin{array}{l}\text { EN AW-Al Mg1(B) } \\
\text { EN AW-AI Mg1(C) } \\
\text { EN AW-AIMg1,5(C) }\end{array}$ & $\begin{array}{l}\mathrm{O}, \mathrm{H} 111, \mathrm{H} 112 \\
\mathrm{O}, \mathrm{H} 111, \mathrm{H} 112 \\
\mathrm{O}, \mathrm{H} 111\end{array}$ \\
\hline & 22.3 & $\begin{array}{l}\text { Stopy } \\
\text { aluminium-magnez } \\
\text { o zawartości } \\
1,5 \%<\mathrm{Mg} \leq 3,5 \%\end{array}$ & $\begin{array}{l}\text { EN AW - } 5049 \\
\text { EN AW - 5052 } \\
\text { EN AW - 5154A } \\
\text { EN AW - 5251 } \\
\text { EN AW - 5454 } \\
\text { EN AW - 5754 }\end{array}$ & $\begin{array}{l}\text { EN AW-Al Mg2Mn0,8 } \\
\text { EN AW-Al Mg2,5 } \\
\text { EN AW-Al Mg3,5(A) } \\
\text { EN AW-Al Mg2 } \\
\text { EN AW-Al Mg3Mn(A) } \\
\text { EN AW-Al Mg3 }\end{array}$ & $\begin{array}{l}\mathrm{O}, \mathrm{H} 111, \mathrm{H} 112 \\
\mathrm{O}, \mathrm{H} 111, \mathrm{H} 112 \\
\mathrm{O}, \mathrm{H} 111, \mathrm{H} 112 \\
\mathrm{O}, \mathrm{H} 111, \mathrm{H} 112 \\
\mathrm{O}, \mathrm{H} 111, \mathrm{H} 112 \\
\mathrm{O}, \mathrm{H} 111, \mathrm{H} 112\end{array}$ \\
\hline & 22.4 & $\begin{array}{l}\text { Stopy } \\
\text { aluminium-magnez } \\
\text { o zawartości } \mathrm{Mg}>3,5 \%\end{array}$ & $\begin{array}{l}\text { EN AW - } 5083 \\
\text { EN AW - } 5086\end{array}$ & $\begin{array}{l}\text { EN AW-Al Mg4,5Mn0,7 } \\
\text { EN AW-Al Mg4 }\end{array}$ & $\begin{array}{l}\mathrm{O}, \mathrm{H} 111, \mathrm{H} 112 \\
\mathrm{O}, \mathrm{H} 111\end{array}$ \\
\hline \multirow[b]{2}{*}{23} & \multicolumn{5}{|c|}{ Stopy obrabiane cieplnie } \\
\hline & 23.1 & $\begin{array}{l}\text { Stopy } \\
\text { aluminium-magnez-krzem }\end{array}$ & $\begin{array}{l}\text { EN AW - } 6060 \\
\text { EN AW - } 6061\end{array}$ & $\begin{array}{l}\text { EN AW-Al MgSi } \\
\text { EN AW-Al Mg1SiCu }\end{array}$ & $\begin{array}{l}\mathrm{T} 4^{\mathrm{a}} \\
\mathrm{T} 4^{\mathrm{b}}, \mathrm{T} 6^{\mathrm{c}}\end{array}$ \\
\hline \multicolumn{6}{|c|}{$\begin{array}{l}\text { a wyłącznie dla kształtowników } \\
\text { b wyłącznie dla rur bez szwu oraz kołnierzy } \\
\text { c wyłącznie dla kołnierzy } \\
\text { Opis stanów wg [4]: } \\
\text { T4 - przesycony i naturalnie starzony do uzyskania stabilnego stanu, } \\
\text { T6 - przesycony a następnie sztucznie starzony, } \\
\text { H111 - stosuje się dla wyrobów, które po końcowym wyżarzeniu są tak dalece umocnione, że nie można ich klasyfikować } \\
\text { jako wyżarzone, jednakże nie są umocnione w takim stopniu jak określa to stan H11, } \\
\text { H112 - stosuje się dla wyrobów, które częściowo cechuje stan odpowiadający przeróbce plastycznej na gorąco lub z określonej } \\
\text { wielkości odkształcenia na zimno i dla których są określone własności mechaniczne, } \\
\text { O - wyżarzony. }\end{array}$} \\
\hline
\end{tabular}

Aluminium i stopy aluminium stosowane do wytwarzania elementów, które nie podlegają zabiegom przeróbki plastycznej na zimno powinny cechować się wydłużeniem nie mniejszym niż 10\% (niezależnie od kierunku pobierania próbek) przy zachowaniu długości pomiarowej $L o=5,65 \sqrt{\text { So }}$

Opisane powyżej wymagania odpowiadają również zapisom w PN-EN 12392:2000 [3], która dodatkowo zawiera szereg innych informacji, w szczególności dotyczących warunków technicznych kontroli i dostawy wyrobów (blach, rur, odkuwek), zdolności do spawania (procesami 141, 131, 15) oraz maksymalnych temperatur pracy dla poszczególnych rodzajów stopów.

W odniesieniu do zagadnienia kruchego pękania i zastosowań w niskich temperaturach pracy norma [1] przywołuje punkt 4.3 normy PN-EN 1252-1 [2] zgodnie z którym ciągliwość aluminium i stopów aluminium jest wysoka w niskiej temperaturze.

Próby udarności nie są wymagane ponieważ aluminium i jego stopy nie wykazują krzywej przejścia w stan kruchy, która jest cechą charakterystyczną dla wielu rodzajów stali.

\section{Wymagania szczegółowe dotyczące niektórych rodzajów złączy [1]}

Złącza zakładkowe ze spoinami pachwinowymi w zbiornikach ciśnieniowych mogą być stosowane gdy spełnione są wszystkie z poniższych warunków:

- wybrano grupę badań 4 (zgodnie z tabl. III),

- materiały podstawowe należą do grup 21 lub 22 i wyszczególnione są w tablicy I,

- zastosowanie ograniczone jest dla przypadku połączenia płaszcza z dnem,

- największa nominalna grubość każdego z elementów w połączeniu nie przekracza $8 \mathrm{~mm}$,

- minimalna wielkość zakładki wynosi 4e (e - największa grubość nominalna elementów w złączu),

- spoiny występują po obu stronach zakładki,

- maksymalna średnica zewnętrzna zbiornika nie przekracza $1600 \mathrm{~mm}$,

- nie występuje ryzyko korozji. 
Spoiny czołowe w złączu z występem centrującym (rys. 1) w zbiornikach ciśnieniowych mogą być stosowane gdy spełnione są wszystkie z poniższych warunków:

- materiały podstawowe należą do grup 21 lub 22 i wyszczególnione są w tablicy I przy czym niedopuszczalne jest stosowanie stopu 5454,

- zastosowanie ograniczone jest dla przypadku połączenia płaszcza z dnem,

- największa nominalna grubość każdego z elementów w połączeniu nie przekracza $12 \mathrm{~mm}$,

- brak ryzyka korozji od strony wewnętrznej zbiornika,

- obszar przecięcia spoiny wzdłużnej z obwodową powinien być poddany badaniom radiograficznym w celu zapewnienia, że nie występują niezgodności niedopuszczalne,

- maksymalna średnica zewnętrzna zbiornika nie przekracza $1600 \mathrm{~mm}$.

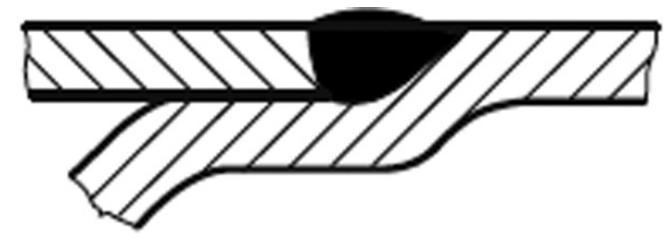

Rys. 1. Spoina czołowa w złączu z występem centrującym Fig. 1. Test joint made of S690QL steel plate

Podkładki pozostające mogą być stosowane wyłącznie w przypadku złączy obwodowych oraz złączy blach do wytwarzania płaszczy oraz den zbiorników gdy spełnione są wszystkie z poniższych warunków:

- badania nieniszczące są wykonywane odpowiednio do wartości współczynnika złącza przy zachowaniu kryteriów jakości i akceptacji charakterystycznych dla spoin doczołowych jednostronnych,

- brak ryzyka korozji od strony wewnętrznej zbiornika,

- materiał podkładki powinien należeć do tej samej podgrupy co materiał zbiornika chyba, że przeprowadzono oddzielne kwalifikowanie technologii spawania dla innego materiału podkładki.

\section{Kwalifikowanie technologii spawania oraz egzaminowanie spawaczy}

Kwalifikowanie technologii spawania powinno być przeprowadzone zgodnie z wymaganiami PN-EN ISO 156142:2008. Uwzględnić należy jednak dodatkowe wymagania opisane w normie wyrobu [1]:

- dla blach o grubości równej lub większej niż 20 mm wymagane jest przeprowadzenie próby rozciągania wzdłużnego spoiny zgodnie z PN-EN 876:1999 w celu określenia wartości granicy plastyczności Re, wytrzymałości na rozciąganie $\mathrm{Rm}$ oraz wydłużenia $\mathrm{A}$,

- zakres kwalifikacji dla grubości materiału podstawowego w przypadku spoin czołowych jednościegowych w złączu jednostronnym lub dwuściegowych w złączu dwustronnym (po jednym ściegu z każdej strony) ograniczony jest do wartości 0,8t do t (gdzie t - grubość złącza próbnego). Egzaminowanie spawaczy powinno być realizowane na podstawie PN-EN ISO 9606-2.

\section{Wymagania dotyczące technologii spawania}

Norma [1] określa jedynie opisane poniżej wymagania dotyczące przygotowania brzegów łączonych elementów, podgrzewania wstępnego oraz obróbki cieplnej po spawaniu.
Podczas przygotowania brzegów elementów podlegających łączeniu przestrzegać należy następujących zasad:

- cięcie i ukosowanie może być wykonywane za pomocą obróbki mechanicznej lub procesów termicznych np. cięcia plazmowego. Dopuszczalne jest kształtowania brzegów z zastosowaniem procesów hydro-mechanicznych;

- dla blach o grubości nie większej niż 25 mm dopuszcza się stosowanie wykrawania;

- wszystkie krawędzie niezależnie od stosowanego procesu cięcia powinny być poddane końcowej obróbce mechanicznej chyba, że wytwórca udowodni brak wpływu technologii cięcia na własności materiału podstawowego w szczególności jego spawalność;

- przed rozpoczęciem procesu spawania brzegi łączonych elementów powinny być poddane obróbce mechanicznej lub trawieniu w celu usunięcia tlenków aluminium i zanieczyszczeń. Niedopuszczalne jest stosowanie środków zawierających związki chloru.

Norma [1] nie obejmuje zagadnień doboru szczegółów złączy m.in. kąta ukosowania, odstępu, wysokości progu, podkładki, itp. W tym przypadku wykorzystać można zalecenia opisane w PN-EN ISO 9692-3:2004+A1:2005 [7].

Podgrzewanie wstępne aluminium i jego stopów nie jest wykonywane $z$ uwagi na czynniki metalurgiczne. Zabieg ten może natomiast okazać się niezbędny w celu usunięcia wilgoci z powierzchni elementów. Norma zaleca wtedy podgrzewanie do temperatury ok. $50^{\circ} \mathrm{C}$. W przypadku stopów aluminium zawierających magnez w ilości równej lub większej od 3\%, temperatura wstępnego podgrzewania oraz międzyściegowa równa lub większa od $150{ }^{\circ} \mathrm{C}$ może powodować pojawienie się na granicach ziaren wydzieleń fazy $\mathrm{Al}_{3} \mathrm{Mg}_{2}$, które są przyczyną kruchości złącza.

Wyżarzanie odprężające po spawaniu nie powinno być stosowane za wyjątkiem przypadków gdy występuje ryzyko korozji naprężeniowej. Wyżarzanie w celu uzyskania własności charakterystycznych dla stanu dostawy ' $O$ ' jest jedynym dopuszczalnym rodzajem obróbki cieplnej po spawaniu, która powinna być przeprowadzana zgodnie ze specyfikacją materiału podstawowego. Dla złączy ze stopów aluminium grupy 23.1 obróbka cieplna po spawaniu jest niedopuszczalna.

Wytyczne dotyczące technologii spawania przedstawione są również w PN-EN 1011-4 [6], która nie jest przywołana w normie wyrobu [1] jako dokument odniesienia. Opisuje jednak w sposób bardziej szczegółowy omówione powyżej zagadnienia (za wyjątkiem obróbki cieplnej po spawaniu) oraz określa wytyczne dotyczące m.in. temperatury międzyściegowej, doboru spoiw i gazów osłonowych. Wymienia również podstawowe przyczyny niezgodności w złączach spawanych i proponuje odpowiednie działania zapobiegawcze.

\section{Wykonanie i badania produkcyjnych płyt próbnych w odniesieniu do złączy spawanych [1]}

W trakcie procesu produkcyjnego zbiorników ciśnieniowych wykonuje się płyty próbne, które podlegają odpowiednim badaniom w celu zapewnienia, że technologię spawania wdrożono właściwie a elementy ciśnieniowe cechują się odpowiednimi własnościami.

Podczas wytwarzania zbiorników ciśnieniowych obowiązują następujące zasady:

a) dla złączy spawanych w zbiornikach kwalifikowanych do grupy badań 4 (zgodnie z tabl. III) nie wymaga się przeprowadzania badań produkcyjnych; 
b) dla aluminium i jego stopów z grup 22.1, 22.2, 22.3 (za wyjątkiem stopu 5454) oraz 22.4 badania produkcyjne nie są wymagane jeżeli występują jednocześnie następujące warunki:

- spełnione są wymagania jakościowe w spawalnictwie określone w normach PN-EN ISO 3834-2 lub -3;

- proces spawania jest w pełni zmechanizowany,

- Instrukcja Technologiczna Spawania nie zawiera wymagań dotyczących podgrzewania wstępnego lub obróbki cieplnej po spawaniu;

- grubość nominalna ścianki zbiornika nie przekracza $30 \mathrm{~mm}$;

c) w przypadkach innych niż określone w pkt a) lub b) liczba płyt próbnych jest następująca:

- 1 płyta próbna na zbiornik dla spoin wzdłużnych gdy współczynnik wytrzymałości złącza jest równy 1 ;

- 1 płyta próbna na każde 200 m spoin wzdłużnych w przypadku współczynnika wytrzymałości złącza 0,85 lub połączeń elementów den za wyjątkiem den kulistych gdy ww. współczynnik jest równy 1;

- 1 płyta próbna na rok dla spoin czołowych obwodowych w złączach z występem centrującym lub z podkładką pozostającą;

Po badaniach z wynikiem pozytywnym 10 kolejnych płyt próbnych można zmniejszyć zakres w sposób następujący:

- 1 płyta próbna na każde 200 m spoin wzdłużnych gdy współczynnik wytrzymałości złącza jest równy 1 ;

- 1 płyta próbna na każde 1500 m spoin wzdłużnych gdy współczynnik wytrzymałości złącza jest równy 0,85 lub połączeń elementów den za wyjątkiem den kulistych gdy ww. współczynnik jest równy 1 ;

- 1 płyta próbna na rok dla spoin czołowych obwodowych w złączach z występem centrującym lub z podkładką stapianą.

Zakres badań płyt próbnych opisano w tablicy II.

\section{Kontrola i badania zbiorników ciśnieniowych [1]}

Podstawą wyznaczania rodzaju i zakresu badań dla zbiorników ciśnieniowych jest ich przyporządkowanie do tzw. grup badań zgodnie z tablicą III.

Bardzo ważnym zagadnieniem przy wyznaczaniu zakresu badań nieniszczących jest nie tylko posługiwanie się w odpowiedni sposób właściwą tabelą normy ale również uwzględnienie szeregu wymagań szczegółowych. Zakresy badań nieniszczących określone dla poszczególnych rodzajów złączy (tabl. IV) obowiązują wyłącznie dla spawania techniką wielościegową metodami 131 i 141. Specjalne podejście wymagane jest dla złączy wzdłużnych wykonywanych z zastosowaniem:

- innych procesów spajania, np. 15 (spawanie plazmowe), 51 (spawanie elektronowe), 42 (zgrzewanie tarciowe);

- spawania techniką jednościegową (dotyczy również przypadku złączy dwustronnych gdy z każdej strony ułożony jest tylko jeden ścieg);

- procesów spawania automatycznego (definicja procesu występuje w normach PN-EN 1418 oraz PN-EN ISO 14732).

Norma nie określa wytycznych dla ww. przypadków szczególnych za wyjątkiem spawania techniką jednościegową złączy wzdłużnych. Można wykorzystać wtedy zapis występujący w pkt 6.6.2.3.2 normy PN-EN 13445-5 zgodnie z którym zakres badań może być zwiększony dwukrotnie, nie może być jednak mniejszy niż 25\%.

Pamiętać również należy o szczegółowych zasadach postępowania gdy wymagany zakres badań jest mniejszy niż $100 \%$. Obowiązują wtedy następujące wymagania dotyczące wyboru obszaru do badań:

a) złącza płaszczy, den po przeróbce plastycznej, komór komunikacyjnych i osłon:

- badania nieniszczące powinny być wykonane we wszystkich obszarach przecięcia się spoin wzdłużnych i obwodowych. Minimalna długość badania powinna wynosić $200 \mathrm{~mm}$. Wymaganie powinno być stosowane nawet wtedy gdy włączenie wszystkich ww. obszarów powoduje przekroczenie zakresu procentowego wskazanego w tablicy IV;

- spoiny króćców w obrębie lub w odległości mniejszej niż $12 \mathrm{~mm}$ od spoin głównych (wzdłużnych lub obwodowych) powinny być poddane badaniom nieniszczącym na całej długości od strony zewnętrznej i wewnętrznej. Wymaganie to należy traktować jako dodatkowe w odniesieniu do zakresu badań określonego w tablicy IV;

b) wszystkie króćce i odgałęzienia połączone ze zbiornikiem spoinami czołowymi powinny podlegać grupowaniu w celu ustalenia zakresu badań:

- dla zakresu badań 100\% - liczność grup wynosi 1 (t.j. badaniu podlega cała długość spoiny każdego króćca lub odgałęzienia),

- dla zakresu badań 25\% - liczność grup wynosi 4 (t.j. badaniom podlega cała długość spoiny co najmniej jednego króćca lub odgałęzienia każdej z 4 grup),

- dla zakresu badań 10\% - liczność grup wynosi 10 (t.j. badaniom podlega cała długość spoiny co najmniej jednego króćca lub odgałęzienia każdej z 10 grup).

Tablica II. Badania produkcyjnych płyt próbnych

Table II. Testing of production test plates

\begin{tabular}{|c|c|c|}
\hline Gr. materiałów & Grubość nominalna $\mathrm{e}_{\mathrm{n}}{ }^{\mathrm{a}}[\mathrm{mm}]$ & Próbki do badań \\
\hline \multirow[t]{2}{*}{$\begin{array}{c}21,22.1,22.2 \\
22.3,22.4,23.1\end{array}$} & $\leq 35$ & $\begin{array}{l}1 \text { próbka dla próby gięcia z rozciąganiem od strony lica wg PN-EN 910:1999 } \\
1 \text { próbka dla próby gięcia z rozciąganiem od strony grani wg PN-EN } \\
910: 1999 \text { (dla grubości } e_{n}>12 \text { mm można zastosować } 2 \text { próbki dla zginania } \\
\text { bocznego) wg PN-EN 910:1999 } \\
1 \text { próbka dla próby rozciągania poprzecznego wg PN-EN 895:1997 } \\
1 \text { próbka dla badań makroskopowych wg PN-EN 1321:2000 }\end{array}$ \\
\hline & $\geq 35$ & $\begin{array}{l}2 \text { próbki dla zginania bocznego wg PN-EN 910:1999 } \\
1 \text { próbka dla próby rozciągania poprzecznego wg PN-EN 895:1997 } \\
1 \text { próbka dla badań makroskopowych wg PN-EN 1321:2000 } \\
1 \text { próbka dla próby rozciągania wzdłużnego wg PN-EN 876:1999 }\end{array}$ \\
\hline
\end{tabular}


Tablica III. Grupy badań dla zbiorników ciśnieniowych wytwarzanych z aluminium i jego stopów

Table III. Testing groups for aluminium pressure vessels

\begin{tabular}{|c|c|c|c|c|}
\hline & \multicolumn{4}{|c|}{ Grupy badań } \\
\hline & 1 & $2 a$ & 3 & $4^{\mathrm{h}}$ \\
\hline Materiały podstawowe ${ }^{\mathrm{e}}$ & $21,22.1$ do 22.4 & $\begin{array}{c}21,22.1 \text { do } 22.4 \\
23.1^{g}\end{array}$ & $\begin{array}{c}21,22.1 \text { do } 22.4 \\
23.1^{9}\end{array}$ & $\begin{array}{c}21,22.1 \text { do } 22.4 \\
\text { (za wyjątkiem EN AW 5454) }\end{array}$ \\
\hline $\begin{array}{l}\text { Zakres badań NDT } \\
\text { dla głównych złączy spawanych c,f }\end{array}$ & $100 \%$ & $100 \%-10 \%{ }^{b}$ & $10 \%$ & $0 \%$ \\
\hline $\begin{array}{l}\text { Badania NDT } \\
\text { dla innych złączy spawanych }\end{array}$ & \multicolumn{4}{|c|}{ Określono dla każdego rodzaju złącza w tabeli IV } \\
\hline Współczynnik złącza & 1 & 1 & 0,85 & 0,7 \\
\hline $\begin{array}{l}\text { Maksymalna grubość ścianki dla której } \\
\text { można stosować materiały podstawowe }\end{array}$ & Brak ograniczeń ${ }^{d}$ & $40 \mathrm{~mm}$ & $40 \mathrm{~mm}$ & $20 \mathrm{~mm}$ \\
\hline Proces spawania & Brak ograniczeń d & $\begin{array}{c}\text { Spawanie } \\
\text { zmechanizowane }^{\text {a }} \\
\end{array}$ & Brak ograniczeń d & Brak ograniczeń d \\
\hline Zakres temperatury roboczej & Brak ograniczeń $^{d}$ & Brak ograniczeń ${ }^{d}$ & Brak ograniczeń $^{d}$ & Brak ograniczeń $^{d}$ \\
\hline \multicolumn{5}{|c|}{$\begin{array}{l}\text { a Definicja ww. procesu występuje w PN-EN } 1418 \text { oraz PN-EN ISO } 14732 \\
\text { b Zakres } 100 \% \text { może dotyczyć każdego przypadku natomiast } 10 \% \text { - po spełnieniu warunku 'zadowalającego doświadczenia'. } \\
\text { Termin 'zadowalające doświadczenie' dotyczy minimalnej liczby zbiorników lub długości spoin wykonanych według odpowiedniej kwali- } \\
\text { fikowanej technologii i poddanych badaniom z wynikiem pozytywnym. Obowiązują następujące zasady: } \\
\text { - w przypadku grup materiałów } 21,22.1 \text { do } 22.4 \text { za wyjątkiem EN AW } 5454-25 \text { kolejnych zbiorników lub } 50 \text { m głównych złączy spawanych, } \\
\text { - w przypadku materiałów grupy } 23.1 \text { oraz EN AW } 5454 \text { - } 50 \text { kolejnych zbiorników lub } 100 \text { m głównych złączy spawanych; } \\
\text { - wykazanie 'zadowalającego doświadczenia' w odniesieniu do grupy materiałów } 22.4 \text { powoduje, że spełniony jest również ten waru- } \\
\text { nek dla grup materiałów 21, } 22.1,22.2 \text { i } 22.3, \\
\text { - gdy dowolna niezgodność wymaga naprawy to procedura wykazania 'zadowalającego doświadczenia' musi być rozpoczęta ponownie. } \\
\text { c Patrz szczegóły dotyczące badań opisane w tablicy IV, } \\
\text { d Termin 'Brak ograniczeń' dotyczy wyłącznie badań. Norma wprowadza wiele innych ograniczeń związanych np. z projektowaniem, } \\
\text { zastosowaniem materiałów w określonych temperaturach roboczych, itp. } \\
\text { e Patrz tablica I, } \\
\text { f Procent spoin w określonym zbiorniku, } \\
\text { g W przypadku stopu grupy } 23.1: \\
\text { - poszczególne główne elementy ciśnieniowe (np. płaszcz, dna, kołnierze) oraz połączenia króćców nie mogą być wytwarzane } \\
\text { jako spawane; dopuszcza się wyłącznie spoiny obwodowe łączące oddzielne elementy, } \\
\text {-niedopuszczalna jest przeróbka plastyczna na zimno. } \\
\text { h Grupę można stosować dla maksymalnego dopuszczalnego ciśnienia PS } \leq 20 \text { bar, maksymalnej liczba cykli } \leq 500 \text { oraz niższego pozio- } \\
\text { mu nominalnych naprężeń projektowych (zgodnie z PN-EN 13445-3:2009) }\end{array}$} \\
\hline
\end{tabular}

Tablica IV. Zakres badań nieniszczących

Table IV. Extent of non destructive testing

\begin{tabular}{|c|c|c|c|c|c|c|c|}
\hline & Grupa badań & 1 & 2 & 3 & 4 \\
\hline & & & $\begin{array}{c}\text { Materiały } \\
\text { podstawowe }\end{array}$ & $\begin{array}{l}21,22.1 \\
\text { do } 22.4\end{array}$ & $\begin{array}{r}21,22.1 \\
\text { do } 22.4\end{array}$ & $\begin{array}{c}21,22.1 \\
\text { do } 22.4 \text { i } 23.1\end{array}$ & $\begin{array}{c}21,22.1 \text { do } 22.4 \\
\text { (za wyjątkiem } \\
\text { EN AW 5454) } \\
\end{array}$ \\
\hline \multicolumn{3}{|r|}{ Rodzaj spoiny a } & Rodzaj badania ${ }^{\mathrm{b}}$ & \multicolumn{4}{|c|}{ Zakres badania } \\
\hline \multirow{10}{*}{$\begin{array}{l}\text { Spoiny } \\
\text { czołowe } \\
\text { z pełnym } \\
\text { przetopem }\end{array}$} & 1 & Złącze wzdłużne & $\begin{array}{l}\text { RT lub UT } \\
\text { PT }\end{array}$ & $\begin{array}{c}100 \% \\
0\end{array}$ & $\begin{array}{c}(100-10) \%^{p} \\
0\end{array}$ & $\begin{array}{c}10 \%^{p} \\
0\end{array}$ & $\begin{array}{c}0^{p} \\
0\end{array}$ \\
\hline & $2 a$ & Złącze obwodowe płaszcza & $\begin{array}{l}\text { RT lub UT } \\
\text { PT }\end{array}$ & $\begin{array}{c}25 \% \\
0\end{array}$ & $\begin{array}{c}(25-10) \% \\
0\end{array}$ & $\begin{array}{l}10 \%^{c} \\
0\end{array}$ & $\begin{array}{l}0 \\
0\end{array}$ \\
\hline & $2 b$ & $\begin{array}{l}\text { Złącze obwodowe płaszcza } \\
\text { z podkładką pozostającą k }\end{array}$ & $\begin{array}{l}\text { RT lub UT } \\
\text { PT }\end{array}$ & $\begin{array}{c}25 \% \\
0\end{array}$ & $\begin{array}{c}(25-10) \% \\
0\end{array}$ & $\begin{array}{c}10 \% \\
0\end{array}$ & $\begin{array}{l}0 \\
0\end{array}$ \\
\hline & 2c & $\begin{array}{l}\text { Złącze obwodowe z występem centrują- } \\
\text { cym ze spoiną czołową }{ }^{k}\end{array}$ & $\begin{array}{l}\text { RT lub UT } \\
\text { PT }\end{array}$ & $\begin{array}{c}25 \% \\
0\end{array}$ & $\begin{array}{c}(25-10) \% \\
0\end{array}$ & $\begin{array}{c}10 \% \\
0\end{array}$ & $\begin{array}{l}0 \\
0\end{array}$ \\
\hline & $3 a$ & $\begin{array}{l}\text { Złącza obwodowe króćców dla Di> } 150 \mathrm{~mm} \\
\text { lub e>16 mm }\end{array}$ & $\begin{array}{l}\text { RT lub UT } \\
\text { PT }\end{array}$ & $\begin{array}{c}25 \% \\
0\end{array}$ & $\begin{array}{c}(25-10) \% \\
0 \\
\end{array}$ & $\begin{array}{c}10 \%^{\mathrm{c}} \\
0\end{array}$ & $\begin{array}{l}0 \\
0\end{array}$ \\
\hline & $3 b$ & $\begin{array}{l}\text { Złącza obwodowe króćców dla Di>150 mm } \\
\text { lub e>16 mm z podkładką pzostającą k }\end{array}$ & $\begin{array}{l}\text { RT lub UT } \\
\text { PT }\end{array}$ & $\begin{array}{c}25 \% \\
0\end{array}$ & $\begin{array}{c}(25-10) \% \\
0\end{array}$ & $\begin{array}{c}10 \% \\
0\end{array}$ & $\begin{array}{l}0 \\
0\end{array}$ \\
\hline & 4 & $\begin{array}{l}\text { Złącza obwodowe króćców dla Di }<150 \mathrm{~mm} \\
\text { lub e }<16 \mathrm{~mm}\end{array}$ & $\begin{array}{l}\text { RT lub UT } \\
\text { PT }\end{array}$ & $\begin{array}{c}0 \\
50 \% \\
\end{array}$ & $\begin{array}{c}0 \\
(50-10) \% \\
\end{array}$ & $\begin{array}{c}0 \\
10 \%^{\mathrm{d}} \\
\end{array}$ & $\begin{array}{l}0 \\
0\end{array}$ \\
\hline & 5 & $\begin{array}{l}\text { Wszystkie spoiny płaszcza, den oraz spo- } \\
\text { iny łączące płaszcz z dnem kulistym }\end{array}$ & $\begin{array}{l}\text { RT lub UT } \\
\text { PT }\end{array}$ & $\begin{array}{c}100 \% \\
0\end{array}$ & $\begin{array}{c}100 \% \\
0\end{array}$ & $\begin{array}{c}10 \%^{p} \\
0\end{array}$ & $\begin{array}{l}0^{p} \\
0\end{array}$ \\
\hline & 6 & $\begin{array}{l}\text { Połączenie płaszcza stożkowego o kącie } \\
\leq 30^{\circ} \text { z płaszczem cylindrycznym }\end{array}$ & $\begin{array}{l}\text { RT lub UT } \\
\text { PT }\end{array}$ & $\begin{array}{c}25 \% \\
0\end{array}$ & $\begin{array}{c}(25-10) \% \\
0 \\
\end{array}$ & $\begin{array}{c}10 \% \\
0\end{array}$ & $\begin{array}{l}0^{p} \\
0\end{array}$ \\
\hline & 7 & $\begin{array}{l}\text { Połączenie płaszcza stożkowego o kącie } \\
>30^{\circ} \text { z płaszczem cylindrycznym }\end{array}$ & $\begin{array}{l}\text { RT lub UT } \\
\text { PT }\end{array}$ & $\begin{array}{c}100 \% \\
0\end{array}$ & $\begin{array}{c}(100-25) \% \\
0\end{array}$ & $\begin{array}{c}10 \% \\
10 \%{ }^{d}\end{array}$ & $\begin{array}{c}10 \% \\
0\end{array}$ \\
\hline
\end{tabular}




\begin{tabular}{|c|c|c|c|c|c|c|c|}
\hline & & & \multirow{3}{*}{\begin{tabular}{|c|} 
Grupa badań \\
Materiały \\
podstawowe
\end{tabular}} & \\
\hline & & & & 1 & 2 & 3 & 4 \\
\hline & & & & $\begin{array}{l}21,22.1 \\
\text { do } 22.4\end{array}$ & $\begin{array}{l}21,22.1 \\
\text { do } 22.4\end{array}$ & $\mid \begin{array}{c}21,22.1 \\
\text { do } 22.4 \text { i } 23.1^{\circ}\end{array}$ & $\begin{array}{c}21,22.1 \text { do } 22.4 \\
\text { (za wyjątkiem } \\
\text { EN AW 5454) } \\
\end{array}$ \\
\hline \multicolumn{3}{|c|}{ Rodzaj spoiny a } & Rodzaj badania ${ }^{\mathrm{b}}$ & \multicolumn{4}{|c|}{ Zakres badania } \\
\hline $\begin{array}{l}\text { Spoiny czołowe } \\
\text { z pełnym przetopem }\end{array}$ & 7 & $\begin{array}{l}\text { Połączenie płaszcza } \\
\text { stożkowego o kącie }>30^{\circ} \\
\text { z płaszczem cylindrycznym }\end{array}$ & $\begin{array}{l}\text { RT lub UT } \\
\text { PT }\end{array}$ & $\begin{array}{c}100 \% \\
0\end{array}$ & $\begin{array}{c}(100-25) \% \\
0\end{array}$ & $\begin{array}{l}10 \% \\
10 \%^{d}\end{array}$ & $\begin{array}{c}10 \% \\
0\end{array}$ \\
\hline $\begin{array}{l}\text { Spoiny pachwinowe } \\
\text { w złączach } \\
\text { zakładkowych k }\end{array}$ & 8 & $\begin{array}{l}\text { Połączenie zakładkowe dna } \\
\text { z płaszczem }\end{array}$ & $\begin{array}{l}\text { RT lub UT } \\
\text { PT }\end{array}$ & $\begin{array}{l}\text { NA } \\
\text { NA }\end{array}$ & $\begin{array}{l}\text { NA } \\
\text { NA }\end{array}$ & $\begin{array}{l}\text { NA } \\
\text { NA }\end{array}$ & $\begin{array}{c}0^{p} \\
0\end{array}$ \\
\hline \multirow{3}{*}{$\begin{array}{l}\text { Złącza den płaskich } \\
\text { lub ścian sitowych } \\
\text { z płaszczem; } \\
\text { Złącza kołnierzy } \\
\text { z płaszczem }\end{array}$} & 9 & Z pełnym przetopem & $\begin{array}{l}\text { RT lub UT } \\
\text { PT }\end{array}$ & $\begin{array}{c}25 \% \\
0 \\
\end{array}$ & $\begin{array}{c}(25-10) \% \\
0 \\
\end{array}$ & $\begin{array}{c}10 \% \\
0^{p}\end{array}$ & $\begin{array}{l}0^{p} \\
0^{p}\end{array}$ \\
\hline & 10 & \begin{tabular}{|l} 
Bez pełnego przetopu \\
jeżeli a>16 mm (rys. 3)
\end{tabular} & $\begin{array}{l}\text { RT lub UT } \\
\text { PT }\end{array}$ & $\begin{array}{l}\text { NA } \\
\text { NA }\end{array}$ & $\begin{array}{l}\text { NA } \\
\text { NA }\end{array}$ & $\begin{array}{c}10 \% \\
0 \\
\end{array}$ & $\begin{array}{l}0 \\
0 \\
\end{array}$ \\
\hline & 11 & $\begin{array}{l}\text { Bez pełnego przetopu } \\
\text { jeżeli a<16 mm (rys. 3) }\end{array}$ & $\begin{array}{l}\text { RT lub UT } \\
\text { PT }\end{array}$ & $\begin{array}{l}\text { NA } \\
\text { NA }\end{array}$ & $\begin{array}{l}\text { NA } \\
\text { NA }\end{array}$ & $\begin{array}{c}0 \\
10 \% \\
\end{array}$ & $\begin{array}{l}0 \\
0 \\
\end{array}$ \\
\hline \multirow{2}{*}{$\begin{array}{l}\text { Złącza kołnierzy } \\
\text { z króćcem } \\
\text { gdy dn }>200 \mathrm{~mm} \\
\mathrm{i} \geq 25 \mathrm{a}\end{array}$} & 12 & Z pełnym przetopem & $\begin{array}{l}\text { RT lub UT } \\
\text { PT }\end{array}$ & $\begin{array}{c}N A \\
25 \%^{9} \\
\end{array}$ & $\begin{array}{c}\text { NA } \\
(25-10) \% \\
\end{array}$ & $\begin{array}{c}\text { NA } \\
10 \% \\
\end{array}$ & $\begin{array}{l}0 \\
0 \\
\end{array}$ \\
\hline & $\begin{array}{l}13, \\
14 \\
\end{array}$ & Bez pełnego przetopu j & $\begin{array}{l}\text { RT lub UT } \\
\text { PT }\end{array}$ & $\begin{array}{l}\text { NA } \\
\text { NA }\end{array}$ & $\begin{array}{l}\text { NA } \\
\text { NA }\end{array}$ & $\begin{array}{c}\text { NA } \\
10 \% \mathrm{dp} \\
\end{array}$ & $\begin{array}{c}0 \\
0^{\mathrm{p}} \\
\end{array}$ \\
\hline \multirow{3}{*}{$\begin{array}{l}\text { Złącza króćców } \\
\text { lub odgałęzień }\end{array}$} & 15 & $\begin{array}{l}\text { Z pełnym przetopem } \\
\text { jeżeli Di }>200 \mathrm{~mm} \text { i e>25 mm }\end{array}$ & $\begin{array}{l}\text { RT lub UT } \\
\text { PT }\end{array}$ & $\begin{array}{c}25 \%^{g} \\
0^{p} \\
\end{array}$ & $\begin{array}{c}(100-10) \% \\
0 \mathrm{p} \\
\end{array}$ & $\begin{array}{c}10 \% \\
0^{p} \\
\end{array}$ & $\begin{array}{c}0 \\
0^{p} \\
\end{array}$ \\
\hline & 16 & $\begin{array}{l}\text { Z pełnym przetopem } \\
\text { jeżeli Di } \leq 200 \mathrm{~mm} \text { i e } \leq 25 \mathrm{~mm}\end{array}$ & $\begin{array}{c}\text { RT lub UT } \\
\text { PT }\end{array}$ & $\begin{array}{c}N A \\
25 \% \text { gp }\end{array}$ & $\begin{array}{c}\text { NA } \\
(25-10) \%^{\mathrm{p}}\end{array}$ & $\begin{array}{c}\text { NA } \\
10 \% \mathrm{dp} \\
\end{array}$ & $\begin{array}{c}0 \\
0^{p} \\
\end{array}$ \\
\hline & $\begin{array}{l}17 \\
18 \\
19\end{array}$ & $\begin{array}{l}\text { Bez pełnego przetopu } \\
\text { niezależnie od wymiaru Di } \\
\text { i a> } 16 \text { mm (rys. 4) }\end{array}$ & $\begin{array}{c}\text { RT lub UT } \\
\mathrm{PT}^{\mathrm{j}}\end{array}$ & $\begin{array}{c}N A \\
25 \% g p\end{array}$ & $\begin{array}{c}\text { NA } \\
(25-10) \%^{p}\end{array}$ & $\begin{array}{l}\mathrm{NA} \\
10 \% \mathrm{dp}\end{array}$ & $\begin{array}{c}0 \\
0^{p}\end{array}$ \\
\hline $\begin{array}{l}\text { Złącza rur } \\
\text { ze ścianami } \\
\text { sitowymi }\end{array}$ & 20 & & $\begin{array}{l}\text { PT lub próba } \\
\text { szczelności q }\end{array}$ & $100 \%$ & $100 \%$ & $10 \%$ & 0 \\
\hline Stałe zamocowania ${ }^{f}$ & 21 & Z lub bez pełnego przetopu & $\begin{array}{c}\text { RT lub UT } \\
\text { PT }\end{array}$ & $\begin{array}{c}0 \\
25 \%^{\mathrm{p}} \\
\end{array}$ & $\begin{array}{c}0 \\
25 \%^{\mathrm{p}} \\
\end{array}$ & $\begin{array}{c}0 \\
25 \%^{\mathrm{p}} \\
\end{array}$ & $\begin{array}{c}0 \\
0^{p}\end{array}$ \\
\hline $\begin{array}{l}\text { Obszary elementów } \\
\text { ciśnieniowych } \\
\text { po usunięciu } \\
\text { zamocowań }\end{array}$ & 22 & & PT & $100 \%$ & $100 \%$ & $100 \%$ & $0^{p}$ \\
\hline $\begin{array}{l}\text { Platerowanie } \\
\text { metodami } \\
\text { spawalniczymi }^{\text {h }} \\
\end{array}$ & 23 & & PT & NA & NA & NA & NA \\
\hline Naprawy & 24 & RT lub UT, PT & $\begin{array}{l}\text { Badania NDT pow } \\
\text { naprawie. Metoda } \\
\text { do rodzaju spoiny }\end{array}$ & $\begin{array}{l}\text { inny obej } \\
\text { badania } \\
\text { zgodnie }\end{array}$ & $\begin{array}{l}\text { mować } 100 \% \\
\text { powinna być } \\
\text { wymagania }\end{array}$ & $\begin{array}{l}\text { \% obszaru podleg } \\
\text { ć wybrana w odni } \\
\text { ami określonymi }\end{array}$ & $\begin{array}{l}\text { Jającego } \\
\text { lesieniu } \\
\text { w niniejszej tabl. } \\
\end{array}$ \\
\hline \multicolumn{8}{|c|}{ 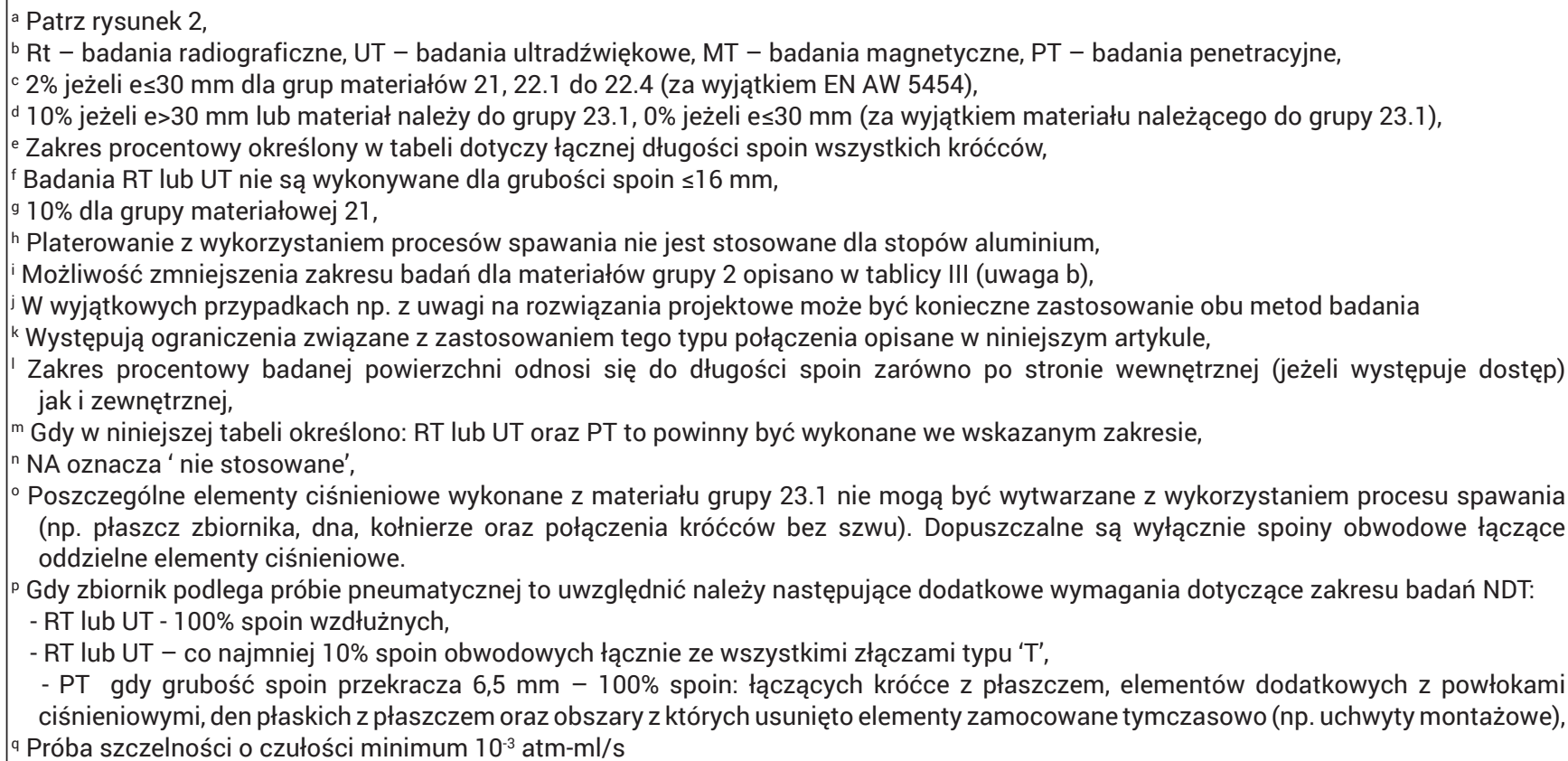 } \\
\hline
\end{tabular}




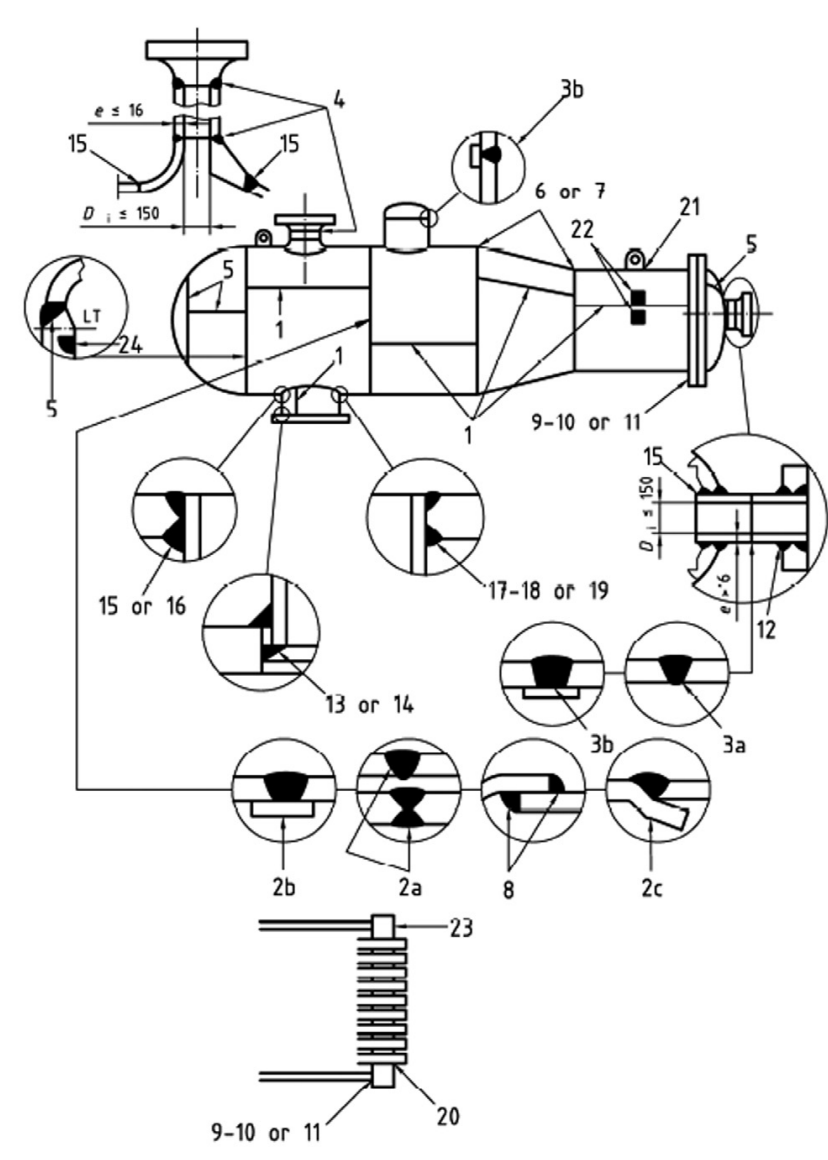

Rys. 2. Rodzaje złączy spawanych w zbiornikach ciśnieniowych Fig. 2. Types of welded joints in pressure vessels

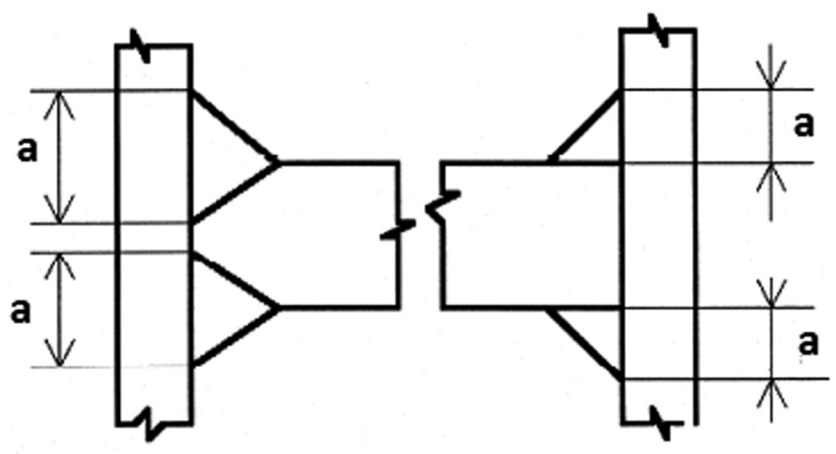

Rys. 3. Definicja wymiaru 'a' dla spoin $\mathrm{nr} 10 \mathrm{i} 11$

Fig. 3. Definition of 'a' dimension for welds no. 10 and 11

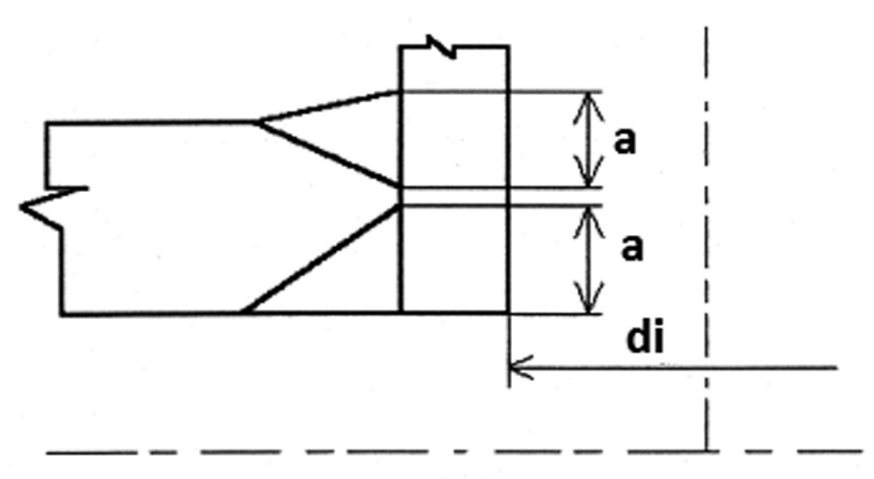

Rys. 4. Definicja wymiaru 'a' dla spoin $\mathrm{nr} 17,18$ i 19

Fig. 4. Definition of 'a' dimension for welds no. 17, 18 and 19

Techniki badań, charakterystykę wskazań oraz kryteria akceptacji dla poszczególnych metod badania zbiorników ciśnieniowych określa tablica V.

Tablica V. Techniki badań, charakterystyka wskazań oraz kryteria akceptacji dla poszczególnych metod badania

Table V. NDT methods, techniques, characterisation, acceptance criteria

\begin{tabular}{|c|c|c|c|}
\hline Metody badań & Technika badania & $\begin{array}{l}\text { Charakterystyka } \\
\text { wskazań }\end{array}$ & Kryteria akceptacji \\
\hline Badania wizualne (VT) & PN-EN 970:1999 & PN-EN ISO 10042:2008 & $\begin{array}{l}\text { PN-EN ISO 10042:2008 - kryteria } \\
\text { akceptacji określono w tablicy VI c }\end{array}$ \\
\hline $\begin{array}{l}\text { Badania radiograficzne } \\
\text { (RT) }\end{array}$ & $\begin{array}{l}\text { PN-EN 1435:2001, } \\
\text { Klasa B a }\end{array}$ & PN-EN ISO 10042:2008 & $\begin{array}{l}\text { PN-EN ISO 10042:2008 - kryteria } \\
\text { akceptacji określono w tablicy VII }\end{array}$ \\
\hline $\begin{array}{c}\text { Badania ultradźwiękowe } \\
\text { (UT) }\end{array}$ & $\begin{array}{c}\text { PN-EN 1714:2002 } \\
\text { dla grubości t }(\mathrm{mm}) \text { : } \\
\text { t<40: klasa A, } \\
40 \leq t<100 \text { : klasa B } \\
\text { t } \geq 100 \text { : klasa C }\end{array}$ & PN-EN 1713:2002 b & $\begin{array}{c}\text { PN-EN 1712:2001; } \\
\text { poziom akceptacji } 2 \\
\text { (niedopuszczalne są jakiekolwiek } \\
\text { niezgodności płaskie) }\end{array}$ \\
\hline $\begin{array}{l}\text { Badania penetracyjne } \\
\text { (PT) }\end{array}$ & $\begin{array}{l}\text { PN-EN 571-1:1999, } \\
\text { PN-EN 1289:1998, } \\
\text { tabela A.1 }\end{array}$ & PN-EN 1289:2000 & $\begin{array}{l}\text { PN-EN 1289:2000 - kryteria } \\
\text { akceptacji określono w tablicy VIII }\end{array}$ \\
\hline \multicolumn{4}{|c|}{$\begin{array}{l}\text { a Jednak maksymalny obszar dla pojedynczej ekspozycji powinien odpowiadać wymaganiom klasy A wg PN-EN 1435:1997, } \\
\text { b PN-EN } 1713 \text { jest jedynie dokumentem zalecanym, } \\
\text { ‘ Wymagania dodatkowe dla następujących niezgodności: } \\
\text { - zajarzenie łuku (601) - konieczne usunięcie i następnie przeprowadzenie badań penetracyjnych w zakresie 100\%, } \\
\text { - rozprysk (602) - niezgodność powinna być usunięta ze wszystkich elementów ciśnieniowych oraz elementów dodatkowych } \\
\text { przenoszących obciążenia, } \\
\text { - naderwanie powierzchni (603) oraz ślady dłutowania (605) - niezgodność podlega szlifowaniu aż do uzyskania łagodnego przejścia, } \\
\text { - przeszlifowanie (606) jest niedopuszczalne. Jakakolwiek niezgodność tego typu powinna być rozpatrywana w odniesieniu do cha- } \\
\text { rakterystyki konstrukcyjnej. }\end{array}$} \\
\hline
\end{tabular}


Kryteria akceptacji dla poszczególnych metod badań zbiorników ciśnieniowych wyszczególniono w tablicach VI $\div$ VIII.

Tablica VI. Kryteria akceptacji dla badań wizualnych

Table VI. Acceptance criteria for visual testing

\begin{tabular}{|c|c|c|}
\hline $\begin{array}{c}\text { Nr niezgodności wg PN-EN ISO 6520:2009 } \\
\text { a }\end{array}$ & Opis niezgodności & Dopuszczalny poziom jakości a \\
\hline 502 & Nadlew spoiny czołowej & PN-EN ISO 10042:2008 - poziom C \\
\hline 503 & $\begin{array}{c}\text { Nadmierna wypukłość spoiny } \\
\text { pachwinowej }\end{array}$ & PN-EN ISO 10042:2008 - poziom C \\
\hline 504 & Wyciek & PN-EN ISO 10042:2008 - poziom C \\
\hline 507 & Przesunięcie liniowe & $\begin{array}{c}\text { Zgodnie z wymaganiami pkt 5.2 } \\
\text { i 5.3 normy PN-EN 13445-4:2009 }\end{array}$ \\
\hline a Dla innych niezgodności wymagany jest poziom jakości B wg PN-EN ISO 10042:2008 &
\end{tabular}

Tablica VII. Kryteria akceptacji dla badań radiograficznych

Table VII. Acceptance criteria for radiographic testing

\begin{tabular}{|c|c|c|}
\hline$\underset{\mathrm{a}}{\text { Nr niezgodności wg PN-EN ISO 6520:2009 }}$ & Opis niezgodności & Dopuszczalny poziom jakości a \\
\hline \multirow{2}{*}{2016} & $\begin{array}{c}\text { Pęcherz kanalikowy } \\
\text { pojedynczy }\end{array}$ & PN-EN ISO 10042:2008 - poziom C \\
\hline & $\begin{array}{c}\text { Pęcherze kanalikowe } \\
\text { zgrupowane }\end{array}$ & Niezgodność niedopuszczalna \\
\hline 303 & Wtrącenie tlenku & PN-EN ISO 10042:2008 - poziom C \\
\hline 3041 & $\begin{array}{l}\text { Wtrącenie metaliczne } \\
\text { wolframu }\end{array}$ & PN-EN ISO 10042:2008 - poziom C \\
\hline 2011 & Pęcherz gazowy & PN-EN ISO 10042:2008 - poziom C \\
\hline 2013 & $\begin{array}{l}\text { Skupisko porowatości } \\
\text { (umiejscowione) }\end{array}$ & PN-EN ISO 10042:2008 - poziom C \\
\hline
\end{tabular}

Tablica VIII. Kryteria akceptacji dla badań radiograficznych

Table VIII. Acceptance criteria for radiographic testing

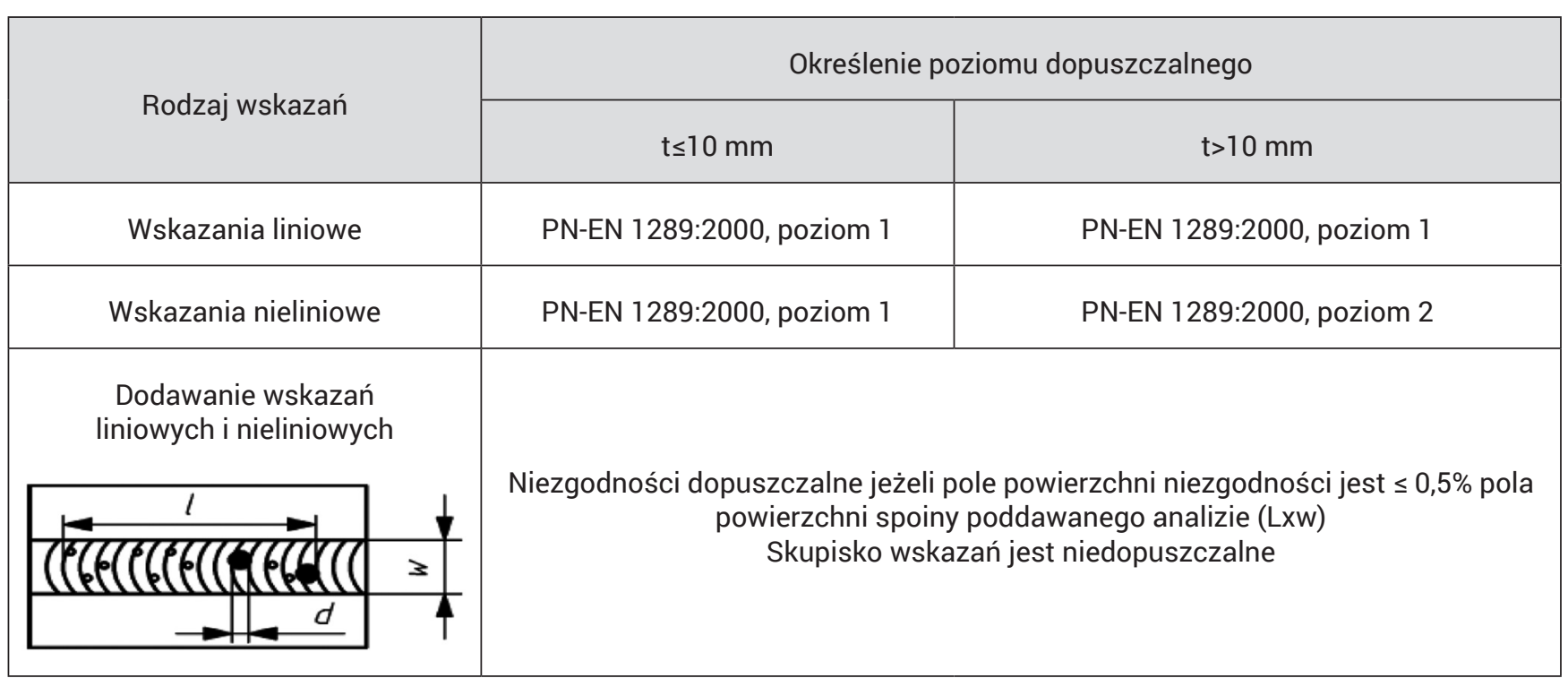


Wybór metody badań nieniszczących objętościowych przeprowadzany jest zgodnie z tablicą IX, która odpowiada wymaganiom określonym w tabeli 3 normy PN-EN 12062:2000 (metoda badania ujęta w nawias oznacza, że jej zakres stosowania jest ograniczony).

Tablica IX. Wybór metody badań nieniszczących a c dla niezgodności wewnętrznych

Table IX. Selection of non destructive testing method a c for determining internal imperfections

\begin{tabular}{|c|c|c|c|c|}
\hline Aluminium i jego stopy & \multicolumn{4}{|c|}{ Nominalna grubość e materiału podstawowego [mm] } \\
\hline Rodzaj złącza & $\mathrm{e} \leq 8$ & $8<\mathrm{e} \leq 40$ & $40<e \leq 100$ & $e>100$ \\
\hline $\begin{array}{l}\text { Złącza doczołowe z pełnym } \\
\text { przetopem }\end{array}$ & $\begin{array}{l}\text { RT klasa B lub } \\
\text { (UT klasa A) }\end{array}$ & $\begin{array}{l}\text { RT klasa B lub } \\
(\text { UT klasa A) }\end{array}$ & 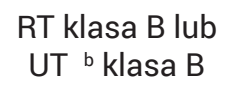 & UT $^{\text {b }}$ klasa $\mathrm{C}$ \\
\hline $\begin{array}{c}\text { Złącza typu T ze spoiną czołową } \\
\text { z pełnym przetopem }\end{array}$ & $\begin{array}{l}\text { RT klasa B lub } \\
\text { UT klasa A }\end{array}$ & $\begin{array}{l}\text { UT klasa A lub } \\
\text { (RT klasa B) }\end{array}$ & $\begin{array}{l}\text { UT klasa B lub } \\
\text { (RT klasa B) }\end{array}$ & UT klasa C \\
\hline \multirow[t]{2}{*}{$\begin{array}{c}\text { Złącza doczołowe lub typu T bez } \\
\text { pełnego przetopu }\end{array}$} & \multicolumn{4}{|c|}{ Grubość spoiny a [mm] } \\
\hline & \multicolumn{4}{|c|}{ a>16 mm - RT klasa B lub UT klasa A } \\
\hline \multicolumn{5}{|c|}{$\begin{array}{l}\text { a RT i UT oznaczają odpowiednio badania radiograficzne i ultradźwiękowe wykonywane wg norm wyszczególnionych w tablicy V, } \\
\text { b Dla e } \geq 60 \text { mm badania UT powinny obejmować niezgodności prostopadłe do powierzchni zgodnie z PN-EN 583-4:2003, } \\
\text { c W niektórych, specjalnych przypadkach wynikających ze stosowanego rozwiązania konstrukcyjnego może okazać się konieczne } \\
\text { zastosowanie obu metod badania, np. w przypadku złączy z niepełnym przetopem }\end{array}$} \\
\hline
\end{tabular}

Norma [1] oprócz opisanych powyżej zagadnień wprowadza także szczegółowe wymagania dotyczące dopuszczalnych naprężeń projektowych, przeróbki plastycznej, obróbki cieplnej po przeróbce plastycznej a także próby ciśnieniowej (hydraulicznej oraz pneumatycznej).

\section{Podsumowanie}

Norma PN-EN 13445-8:2009 uregulowała w znacznym stopniu wytwarzanie zbiorników ciśnieniowych z aluminium i jego stopów. Artykuł ukazuje złożoność wymagań wprowadzanych przez normy europejskie dotyczące poszczególnych rodzajów wyrobów. Personel nadzoru spawalniczego wytwórcy powinien wykazać się dlatego szeroką oraz szczegółową wiedzą ponieważ możliwość nie uwzględnienia jakiegokolwiek z ww. wymagań może zwiększyć ryzyko związane z eksploatacją urządzeń ciśnieniowych.

\section{Literatura}

[1] PN-EN 13445-8:2009 Nieogrzewane płomieniem zbiorniki ciśnieniowe - Część 8: Dodatkowe wymagania dotyczące zbiorników ciśnieniowych wykonanych z aluminium lub stopu aluminium.

[2] PN-EN 1252-1:2002 - Zbiorniki kriogeniczne. Materiały. Część 1: Wymagania dotyczące ciągliwości w temperaturze poniżej $-80^{\circ} \mathrm{C}$.

[3] PN-EN 12392:2004 Aluminium i stopy aluminium - Wyroby przerobione plastycznie - Specjalne wymagania dla wyrobów przeznaczonych do wytwarzania urządzeń ciśnieniowych.

[4] PN-EN 515:1996 Aluminium i stopy aluminium - Wyroby przerobione plastycznie - Oznaczenia stanów.
[5] PN-EN 573-3:2014-02 Aluminium i stopy aluminium - Skład chemiczny i rodzaje wyrobów przerobionych plastycznie - Część 3: Skład chemiczny i rodzaje wyrobów.

[6] PN-EN 1011-4:2002 - Spawanie. Wytyczne dotyczące spawania metali. Część 4: Spawanie łukowe aluminium i stopów aluminium.

[7] PN-EN ISO 9692-3:2004+A1:2005 - Spawanie i procesy pokrewne. Zalecenia dotyczące przygotowanie złączy. Część 3: Spawanie aluminium i jego stopów elektrodą metalową i elektrodą wolframową w osłonie gazów obojętnych. 